\title{
The Effect of Raw Milk Microbial Flora on the Sensory Characteristics of Salers-Type Cheeses
}

\author{
C. Callon, ${ }^{1}$ J. L. Berdagué, ${ }^{2}$ E. Dufour ${ }^{3}$ and M. C. Montel ${ }^{1}$ \\ ${ }^{1}$ Institut National de la Recherche Agronomique, Unité de Recherches Fromagères, \\ 15000 Aurillac, France \\ ${ }^{2}$ Institut National de la Recherche Agronomique, Unité de Recherches sur la viande, \\ laboratoire "flaveur", 63000 Clermont-Ferrand-Theix, France \\ ${ }^{3}$ ENITA, Unité typicité des produits alimentaires, Clermont-Ferrand, France
}

\section{ABSTRACT}

The sensory characteristics of Salers Protected Denomination of Origin raw-milk cheeses are linked to the biochemical composition of the raw material (milk) and to the resultant microbial community. To evaluate the influence of the microbial community on sensory characteristics, Salers-type cheeses were manufactured with the same pasteurized milk, reinoculated with 3 different microbial communities from 3 different filtrates from microfiltered milks. Each cheese was subjected to microbial counts (on selective media), biochemical tests, and volatile and sensory component analyses at different times of ripening. Adding different microbial communities to specimens of the same (biochemically identical) pasteurized milk lead to different sensory characteristics of the cheeses. Cheeses with fresh cream, hazelnut, and caramel attributes were opposed to those with fermented cream, chemical, and garlic flavors. The aromatic compounds identified (esters, acids, alcohols, and aldehydes) in these cheeses were quite similar. Nevertheless, one milk was distinguished by a higher content of acetoin, and lower 2-butanone and 3-methylpentanone concentrations. Over the production period of $1 \mathrm{mo}$, the different cheeses were characterized by the same balance of the microbial population assessed by microbial counts on different media. This was associated with the stability of some sensory attributes describing these cheeses. Nevertheless, there was no linear correlation between microbial flora data and sensory characteristics as measured in this study. (Key words: raw milk, sensory analysis, volatile compounds, Salers cheese)

Abbreviation key: $\mathbf{B P}=$ Baird Parker agar, $\mathbf{C F C}=$ cetrimide-fucidin-cephalosporin medium, $\mathbf{F H}=$ facultative heterofermentative agar, HO = Hoyle medium,

\footnotetext{
Received July 23, 2004.

Accepted July 19, 2005.

Corresponding author: Cécile Callon; e-mail: callon@clermont.
} inra.fr.
MRS = de Man, Rogosa, and Sharpe medium, MSE = Mayeux, Sandine, and Elliker medium, OGA = oxytetracycline glucose agar, $\mathbf{P C A}=$ plate count agar, $\mathbf{P D O}=$ Protected Denomination of Origin, SB = Slanetz Bartley medium.

\section{INTRODUCTION}

The sensory quality of ripened cheeses is determined by the initial microbial and biochemical characteristics of the milk and their evolution during ripening under the influence of technological parameters. Without underestimating the role of other parameters, microorganisms are necessary to the elaboration of sensory characteristics of cheeses through acidification and other metabolic activities. Indeed, whenever the level of microorganisms is reduced by milk pasteurization or microfiltration, microbial cultures (e.g., lactic acid bacteria starter cultures, yeast) must be added in the course of cheese-making process. Centeno et al. (1999) in Cebreiro showed that incorporating Enterococcus faecalis in pasteurized-milk cheeses produced more bitter and acid cheeses, resulted in significant degradation of $\beta$-casein terminal peptides, and in higher scores for yogurt, butter, rancid, and spicy aromas. Likewise, Gomez et al. (1996) obtained less bitter cheeses by incorporating Lactobacillus plantarum spp. in semihard cowmilk cheese.

Comparing the sensory properties of raw-milk cheeses with those of cheeses made from pasteurized or microfiltered milk indicated that milk indigenous microflora were determinant factors of the specific sensory properties of raw-milk cheeses. Grappin and Beuvier (1997) showed that Swiss-type cheeses made from pasteurized or microfiltered milk where only a few culture strains were added featured lower flavor intensity scores than raw-milk cheeses. Furthermore, cheeses made from pasteurized milk were slightly more acid and more bitter than those made from microfiltered milk. All of these intercheese differences could be attributed to the different microflora counts, particularly to the higher populations of facultative heterofermenta- 


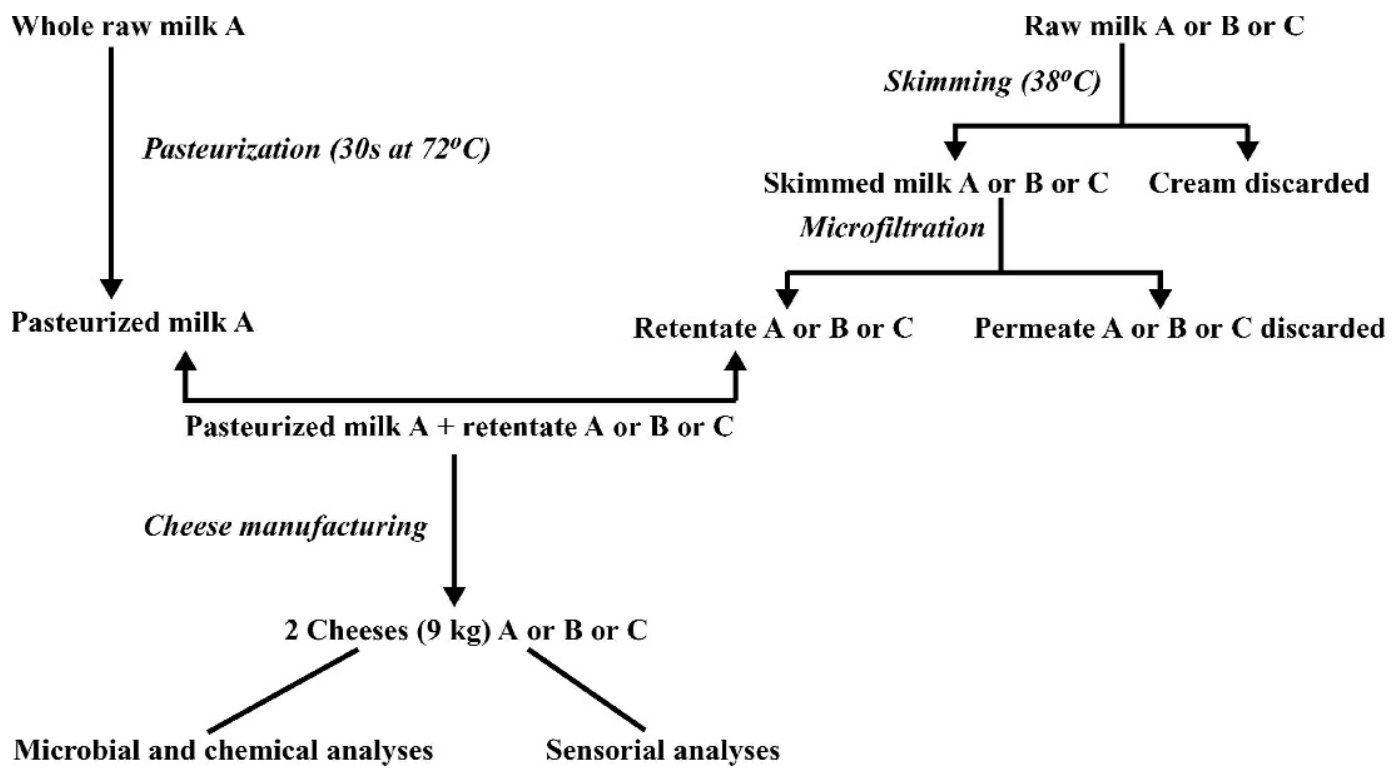

Figure 1. Experimental procedure for the production of Salers-type cheeses.

tive lactobacilli, propionibacteria, and enterococci in raw milk. Grappin and Beuvier (1997) showed furthermore that incorporating of raw-milk microfiltrates in pasteurized milk restored most of the sensory characteristics of raw-milk cheeses. Rehman et al. (2000) obtained similar results in Cheddar cheese, by comparing raw-milk and pasteurized-milk cheeses with those made from pasteurized milk blended with various proportions of raw milk. They showed that sensory assessors awarded increasingly higher scores for fruity/sweet and pungent aromas as the proportion of raw milk increased. They attributed these differences to nonstarter lactic acid bacteria. Buchin et al. (1998), in comparing Morbier-type cheeses made from raw or pasteurized milk, confirmed the higher aromatic intensity of rawmilk cheeses, which were characterized by animal, spiced, garlicky, rancid, and pungent aromas. Cheeses made from pasteurized milk with added commercial starter were characterized by milky and citrus fruit aromas. These sensory differences were correlated with different volatile compound profiles. Raw-milk cheeses exhibited more sulfur, alcohols, and fatty acid compounds, whereas pasteurized-milk cheeses were characterized by a high ketone level. These differences could be ascribed to higher counts of indigenous microflora, such as coliforms, heterofermentative lactobacilli, and enterococci in raw-milk cheeses.

Only one study has been published on the influence of adding different microbial communities to the same microfiltered milk on sensory characteristics of cheese. Demarigny et al. (1997) showed that Gruyère-type cheese manufactured with 3 different microbial commu- nities could be distinguished from their aroma scores and by scores for plasticity, rind, oxidization, pungency, acidity, and firmness. The 3 cheeses were different and could be distinguished from reference cheeses (without bacterial addition).

Salers cheese is a Protected Denomination of Origin (PDO) uncooked, semihard cheese from the Massif Central area of France, made exclusively between May and October with raw milk curdled in a wooden vessel (known as a gerle). It is left to ripen for at least $90 \mathrm{~d}$ and is usually eaten after $150 \mathrm{~d}$ of ripening. The aim of this study was to determine whether variations of milk microbial communities could influence the sensory characteristics of Salers-type cheeses.

\section{MATERIALS AND METHODS}

\section{Experimental Design}

Cheeses were manufactured at INRA's experimental cheese-making unit in Aurillac (France) according to the experimental protocol presented in Figure 1. Raw cows' milk was collected in a "gerle" (wooden vessel) from 3 different cheese farms (A, B, C), in compliance with the specifications of Salers PDO cheeses. The 3 farms were selected according to criteria set in a previous survey (Montel et al., 2001). They differed in their milk production practices and milk microbial counts. They were chosen because of the good quality of the cheeses they produced as defined by the "products agreement commission" of the trade for PDO Salers cheeses (Institut National des Appellations d'Origine). 
Table 1. List of media used for microbial counts and their references and conditions.

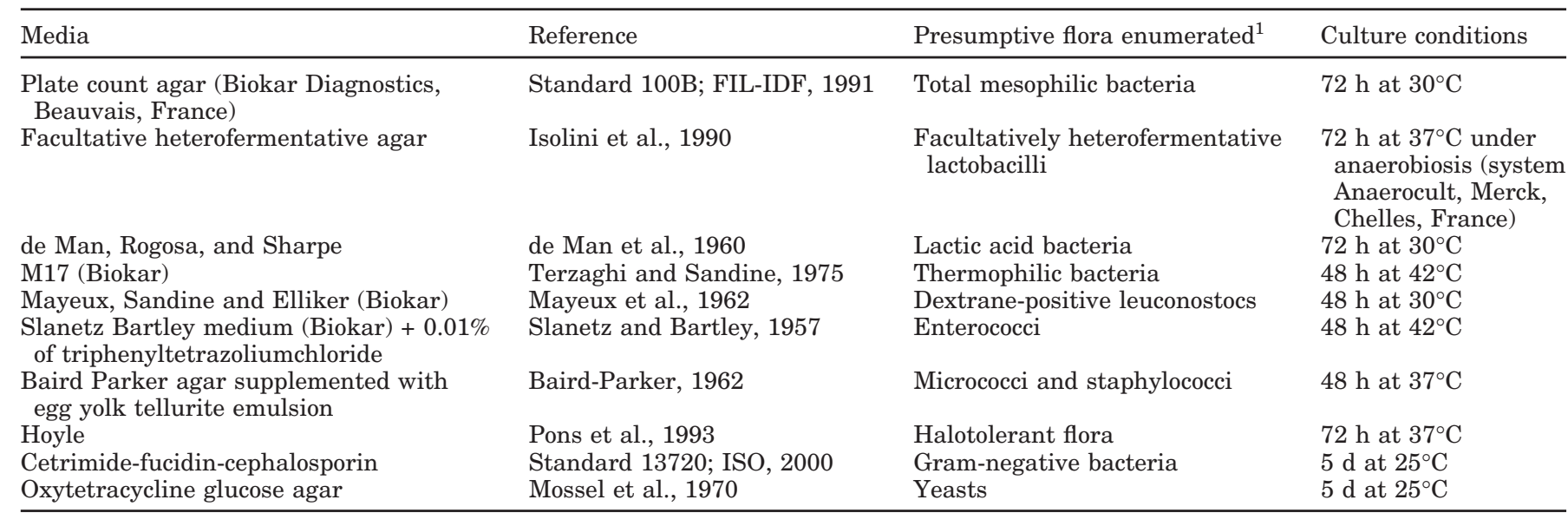

${ }^{1}$ According to Callon et al. (2004) and other literature cited.

The milk specimens were skimmed and microfiltered, using an Alfa-Laval MFS1 cross raw microfiltration unit (Alfa Laval, Les Clayes-sous-Bois, France) with 1.4- $\mu \mathrm{m}$ ceramic membrane pore size, $0.2-\mathrm{m}^{2}$ membrane area, $480 \mathrm{~L} / \mathrm{h}$ per $\mathrm{m}^{2}$ flow rate at $35^{\circ} \mathrm{C}$, and the microfiltrates were preserved at $4^{\circ} \mathrm{C}$ for $2 \mathrm{~h}$. Microfiltrate total flora was rapidly estimated using the direct epifluorescent filter technique with a Biocom automaton (Biocom SA, Courtaboeuf, France; Dasen et al., 1987). Raw milk from farm A was pasteurized $\left(30 \mathrm{~s}\right.$ at $\left.72^{\circ} \mathrm{C}\right)$ and used for all trials. Pasteurized milk was inoculated with either $\mathrm{A}, \mathrm{B}$, or $\mathrm{C}$ milk microfiltrates and the total flora in the final milk was broadly adjusted to $10^{5} \mathrm{cfu} / \mathrm{mL}$ with an adequate volume of microfiltrate. Salers-type cheeses were manufactured without adding any starter culture. The milk was coagulated by adding calf rennet at $31.7^{\circ} \mathrm{C} \pm 0.4^{\circ} \mathrm{C}$. The curd was cut into small pieces and lightly pressed for $100 \mathrm{~min} \pm 20 \mathrm{~min}$ to remove whey. Dry curd was matured for $19.5 \mathrm{~h} \pm 0.5 \mathrm{~h}$. The curd was milled and $2 \% \mathrm{NaCl}$ was added. Further maturation took place during storage for $5 \mathrm{~h} 45 \mathrm{~min} \pm 15$ min at 16 to $18^{\circ} \mathrm{C}$. Then the salted curd was filled into the molds for pressing. Cheeses were pressed at 13 to $14^{\circ} \mathrm{C}$ for $41.5 \mathrm{~h} \pm 1.5$ and turned several times. They were then ripened for $150 \mathrm{~d}$ at $13^{\circ} \mathrm{C}$ and $97 \% \mathrm{RH}$.

One cheese-making process with 1 microfiltered milk was carried out daily. For each milk from the 3 different farms, the cheese fabrication was repeated 3 times over $1 \mathrm{mo}$. Two Salers-type cheeses (final weight $\sim 9 \mathrm{~kg}$ each) were made for each fabrication.

\section{Microbiological Analysis}

Microbial flora of the various milk specimens and cheeses were counted on media under the conditions described in Table 1, at various times of ripening (in milk, and at d 1, 8, 30, 90, and 150). Ten grams of cheese was dissolved in $90 \mathrm{~mL}$ of diluent (solution with $0.8 \% \mathrm{NaCl}, 0.1 \%$ peptone, $0.1 \%$ Tween 80 ). All microbiological analyses were performed in duplicate using a Spiral Plater (Interscience, St-Nom la Bretèche, France) except counts on facultative heterofermentative agar (FH) and de Man, Rogosa, and Sharpe medium (MRS), which were performed by mass inoculation.

\section{Milk Physicochemical Analyses}

Milk fat content and protein contents before renneting were assessed using an automated infrared test method using a MilkoScan apparatus (Milkoscan FT 6000 milk analyzer; Foss Electric, Hillerød, Denmark) according to method FIL-IDF 141B (IDF, 1996). Total milk DM was determined according to a standard method of reference (V 04-367; AFNOR, 1985). Milk lipolysis was assessed by the copper soap method (FILIDF standard 265; IDF, 1991) and milk urea was measured using the colorimetric method (dimethylamino4-benzaldehyde; Martin et al., 1997).

\section{Cheese Physicochemical Analyses}

A pH meter (WTV pH196, Werkstätten, Germany) with a stainless probe (Mettler Toledo, Paris, France) was used for determining cheese $\mathrm{pH}$, by inserting the probe directly in the cheese sample.

Cheese fat content was determined by the acido-butyric method of Heiss (1961). Total nitrogen was determined by the Kjeldahl method (FIL-IDF standard 20B; IDF, 1993). The water-soluble nitrogen was prepared according to Bouton et al. (1994). Briefly, $3 \mathrm{~g}$ of cheese was homogenized with $50 \mathrm{~mL}$ of distilled water for 5 
min with a laboratory blender (Stomacher MIX 1, AES Laboratoire, Combourg, France) and the resulting homogenate was maintained for $1 \mathrm{~h}$ in a water bath at $40^{\circ} \mathrm{C}$. After incubation, the insoluble material was centrifuged at $1200 \times \mathrm{g}$ for $30 \mathrm{~min}$ in a $4^{\circ} \mathrm{C}$ centrifuge. The supernatant was filtered through glass wool, and nitrogen content was determined on a filtrate aliquot by the Kjeldahl method (AOAC, 1990). Cheese DM was determined according to method FIL-IDF 4A (IDF, 1982).

\section{Sensory Assessment}

The sensory characteristics of cheeses were evaluated by quantitative and descriptive analysis after 90 and $150 \mathrm{~d}$ of ripening by a panel of 10 trained assessors. The sensory descriptors were initially defined by the trained panelists. Each sensory attribute was rated on a continuous linear scale ranging from 0 (no perception of the descriptor) to 10 (very intense). The sensory vocabulary used to characterize each cheese included 19 descriptor terms for flavor, 8 for taste (sour, bitter, sweet, salty, metallic, astringent, persistent, and pungent), 19 for aroma, and 7 for texture. Tests were conducted in individual cubicles under red light. All cheese samples were coded and presented simultaneously on individual plates in randomized order, at room temperature.

\section{Cheese Volatile Compound Analyses}

Frozen samples were thawed to room temperature $\left(21^{\circ} \mathrm{C}\right)$ and $5 \mathrm{~g}$ of cheese was mixed with $10 \mathrm{~g}$ of dehydrated sodium sulfate (Prolabo, Lyon, France) before extraction. The volatile compounds of the 150-d-old cheeses were extracted by dynamic headspace method with an automatic Tekmar LSC 2000 system (Tekmar, Cincinnati, OH). One gram of the cheese/ sodium sulfate mixture was placed in a cylindrical glass extractor (40 $\mathrm{mm}$ diameter, $120 \mathrm{~mm}$ high). The volatile compounds were extracted under the following conditions: purge helium flow rate $=65 \mathrm{~mL} / \mathrm{min}$; purging time $=$ $45 \mathrm{~min}$ at $21^{\circ} \mathrm{C}$; dry purge $=15 \mathrm{~min}$; Tekmar trap, Tenax GC; cool-down at $-150^{\circ} \mathrm{C}$; desorb preheat at $220^{\circ} \mathrm{C}$; desorb for $5 \mathrm{~min}$ at $220^{\circ} \mathrm{C}$; inject for $2 \mathrm{~min}$ at $250^{\circ} \mathrm{C}$ in a gas chromatograph maintained at $40^{\circ} \mathrm{C}$; and baking for $30 \mathrm{~min}$ at $225^{\circ} \mathrm{C}$.

The volatile compounds were separated by high-resolution gas chromatography (Hewlett Packard 5890, Les Ulis, France). The chromatographic conditions were: Supelco capillary column $(60 \mathrm{~m} \times 0,32 \mathrm{~mm}$; CH-1196 Gland, Switzerland); stationary phase, SPB5 (1 $\mu \mathrm{m})$; carrier gas, helium at $1 \mathrm{~mL} / \mathrm{min}$; oven temperature was programmed from 40 to $200^{\circ} \mathrm{C}$ with a slope of $3^{\circ} \mathrm{C} / \mathrm{min}$.
The volatile compounds were detected by mass spectrometry with a 5973N Hewlett Packard mass spectrometer (Les Ulis, France). They were then identified by comparing the experimental mass spectra with those contained in the NIST/EPA/MSDC Mass Spectral Database (Royal Society of Chemistry, Cambridge, UK) and by comparing the experimental retention indices with those of the data bank compiled by Kondjoyan and Berdagué (1996). Area was expressed in arbitrary units of surface.

\section{Statistical Analyses}

The effects of added flora on the chemical and microbial characteristics of milks and cheeses and on volatile compounds were studied by 4 analyses of variance using a GLM procedure with STAT-ITCF software (version $5,1991)$ from the Institut Technique des Céréales et des Fourrages (Paris, France). The mathematical model used was $\mathrm{Xi}, \mathrm{k}=\mu+\mathrm{Fl}_{\mathrm{i}}+\Sigma_{\mathrm{k}}$ with $\mathrm{Xi}=$ milk or cheese characteristics, $\mu=$ constant term, $\mathrm{Fl}=$ mean effect of flora ( $\mathrm{i}=3$ represented by $\mathrm{A}, \mathrm{B}$, and $\mathrm{C}$ ), $\Sigma_{\mathrm{k}}=$ residual variance ( $\mathrm{k}=3$ replicates). Whenever a significant difference was noted, Student and Newmann-Keul's tests were applied to identify homogeneous groups $(P<0.05)$. Chemical data analyses were performed on ripening $\mathrm{d}$ $1,8,30$, and 150. Microbial counts were analyzed on the milk and in cheeses at d 1, 8, 30, 90, and 150 . Volatile compounds were assessed in cheeses at $\mathrm{d} 150$.

Two principal component analyses were performed, one on the statistically significant $(P<0.05)$ microbiological-physicochemical data at different times of ripening and the other on the statistically significant $(P<$ 0.05 ) sensory data measured at 90 and $150 \mathrm{~d}$, discriminating the cheeses by ANOVA. The relationships between microbiological and sensory data (all significantly influenced by the flora inoculation) were explored by canonical correlation analysis. This method provides a global measure of the relationships between distinct groups of variables.

All data analyses were carried out using Statistica software (Statistica for Windows, ver 6.1, 2003; Statsoft, Tulsa, OK).

\section{RESULTS AND DISCUSSION}

\section{Milk Physicochemical Analysis}

Milk characteristics are shown in Table 2. There were no significant differences in the protein, fat, urea contents, lipolysis, or $\mathrm{pH}$ of farm A milk specimens, used in all experiments over 1 mo. Protein content was approximately $31 \mathrm{~g} / \mathrm{L}$ and fat content ranged between 33.7 and $35.13 \mathrm{~g} / \mathrm{L}$. Lipolysis was $0.3 \mathrm{mEq} / 100 \mathrm{~g}$, and urea varied between 263.3 and $328.3 \mathrm{mg} / \mathrm{L}$. 
Table 2. Physicochemical characteristics of milks used for preparing cheeses A, B, and C. The results are the mean values from 3 replicate trials. ${ }^{1}$

\begin{tabular}{lcccl}
\hline & $\begin{array}{l}\text { Milk A with } \\
\text { retentate A }\end{array}$ & $\begin{array}{l}\text { Milk A with } \\
\text { retentate B }\end{array}$ & $\begin{array}{l}\text { Milk A with } \\
\text { Retentate C }\end{array}$ & $\begin{array}{l}\text { Statistical } \\
\text { significance }\end{array}$ \\
\hline Protein, g/L & 31.53 & 31.03 & 31.50 & NS $^{2}$ \\
Fat, g/L & 35.13 & 33.7 & 34.83 & NS \\
Lipolysis, mEq/100 g & 0.30 & 0.33 & 0.30 & NS \\
Urea, mg/L & 263.33 & 328.33 & 275 & NS \\
pH & 6.67 & 6.68 & 6.68 & NS \\
\hline
\end{tabular}

${ }^{1}$ All cheeses were made with pasteurized milk A plus retentate (after microfiltration) from raw milks A, $\mathrm{B}$, and $\mathrm{C}$.

${ }^{2} \mathrm{NS}=$ Nonsignificant Newmann-Keuls test $(P>0.05)$.

\section{Physicochemical Composition of Cheeses}

Table 3 shows that the chemical characteristics of cheeses $\mathrm{A}, \mathrm{B}$, and $\mathrm{C}$ did not significantly differ during ripening. Mean fat values ranged between 49.9 and $50.9 \%$ of total weight on $\mathrm{d} 1$ and decreased to between 48.2 and $49.6 \%$ at the end of ripening. Dry matter contents varied between 55.7 and $57.3 \%$ on $\mathrm{d} 1$ and increased to 62.2 and $63.1 \%$ in 150 -d-old cheeses. Total nitrogen contents ranged from 3.72 to $3.91 \%$ at the beginning of ripening. They reached equal levels $(4.2 \%)$ in all cheeses at the end of ripening. Mean soluble proteins/DM values were 0.02 on $d 1$ and reached 0.12 at the end of ripening in all cheeses.

The $\mathrm{pH}$ value at $\mathrm{d} 1$ was significantly different with the highest $\mathrm{pH}$ values for $\mathrm{C}$ cheeses $(\mathrm{pH}=5.3)$. All group $\mathrm{B}$ cheeses were characterized by the lowest $\mathrm{pH}$ values from d 1 until d 90 .

\section{Microbiological Analysis}

Results of ANOVA for the counts of different microbial groups in milks and cheeses at different times of

Table 3. Physicochemical characteristics of cheeses A, B, and C on d 1, 8, 30, and 150. The results are the mean values from 3 replicates.

\begin{tabular}{|c|c|c|c|c|c|}
\hline \multirow[b]{2}{*}{ Parameter } & \multirow{2}{*}{$\begin{array}{l}\text { Age of } \\
\text { cheese, d }\end{array}$} & \multicolumn{3}{|c|}{ Cheese $^{1}$} & \multirow[b]{2}{*}{ Significance } \\
\hline & & $\mathrm{A}$ & $\mathrm{B}$ & $\mathrm{C}$ & \\
\hline \multirow[t]{4}{*}{ Total N, \% wet weight of cheese } & 1 & 3.91 & 3.72 & 3.81 & NS \\
\hline & 8 & 4.13 & 4.10 & 4.17 & NS \\
\hline & 30 & 4.07 & 4.06 & 4.11 & NS \\
\hline & 150 & 4.2 & 4.26 & 4.2 & NS \\
\hline \multirow{4}{*}{ Fat, \% in DM } & 1 & 49.91 & 50.25 & 50.93 & NS \\
\hline & 8 & 49.40 & 49.59 & 51.09 & NS \\
\hline & 30 & 49.54 & 49.56 & 51.10 & NS \\
\hline & 150 & 48.23 & 48.51 & 49.56 & NS \\
\hline \multirow[t]{4}{*}{ DM, \% final weight } & 1 & 57.3 & 55.73 & 56.07 & NS \\
\hline & 8 & 61.59 & 62.02 & 62.15 & NS \\
\hline & 30 & 60.90 & 61.72 & 62.31 & NS \\
\hline & 150 & 62.19 & 63.08 & 62.79 & NS \\
\hline Total N matter/DM & 1 to $150^{2}$ & 0.43 & 0.43 & 0.43 & NS \\
\hline \multirow[t]{4}{*}{ Soluble protein/DM } & 1 & 0.02 & 0.02 & 0.02 & NS \\
\hline & 8 & 0.03 & 0.03 & 0.03 & NS \\
\hline & 30 & 0.04 & 0.05 & 0.05 & NS \\
\hline & 150 & 0.12 & 0.11 & 0.11 & NS \\
\hline \multirow{8}{*}{$\mathrm{pH}$} & $1.5 \mathrm{~h}$ & 6.65 & 6.66 & 6.66 & NS \\
\hline & $7.5 \mathrm{~h}$ & 6.45 & 6.46 & 6.40 & NS \\
\hline & $9.5 \mathrm{~h}$ & 6.39 & 6.33 & 6.19 & NS \\
\hline & $13.5 \mathrm{~h}$ & 5.97 & 5.78 & 5.75 & NS \\
\hline & $22.5 \mathrm{~h}$ & 5.24 & 5.19 & 5.33 & $* * *$ \\
\hline & $72.5 \mathrm{~h}$ & 5.32 & 5.25 & 5.34 & NS \\
\hline & d 90 & 5.64 & 5.62 & 5.62 & NS \\
\hline & d 150 & 5.65 & 5.67 & 5.59 & NS \\
\hline
\end{tabular}

\footnotetext{
${ }^{1}$ All cheeses were made with pasteurized milk A plus retentate (after microfiltration) from raw milks A, B, and C. Cheese A was prepared with milk A plus retentate A; cheese B was prepared with milk A plus retentate $\mathrm{B}$; cheese $\mathrm{C}$ was prepared with milk A plus retentate $\mathrm{C}$.

${ }^{2}$ The value was the same at $d 1,8,30$, and 150 .

*** $P<0.01 ; \mathrm{NS}=$ Nonsignificant level by Newmann-Keuls test $(P>0.05)$.
} 
ripening are shown in Table 4 . Regardless of which cheeses were made with $\mathrm{A}, \mathrm{B}$, and $\mathrm{C}$ milk specimens, the overall microbial count evolution on different media was very similar. Indeed, counts on M17 medium, plate count agar (PCA), Mayeux, Sandine, and Elliker medium (MSE), Baird Parker agar (BP), and cetrimidefucidin-cephalosporin medium (CFC) increased mainly on d 1 , remained stable or decreased slightly to $d 30$, and then decreased. The decrease was particularly marked on CFC medium. Counts on oxytetracycline glucose (OGA) and Hoyle (HO) media increased to d 30 and then decreased. Counts on FH medium increased until d 30 and remained stable thereafter. Nevertheless, the counts on different media at different times of ripening were significantly different between cheeses $\mathrm{A}, \mathrm{B}$, and $\mathrm{C}$, indicating that the microbial ecosystem differed between cheeses.

The 3 cheeses made with microfiltrates from raw milk A were characterized by the lowest counts on PCA, MRS, and M17 media at any time of ripening, on $\mathrm{FH}$ medium in milk until $\mathrm{d} 8$, and on MSE medium in milk until $\mathrm{d} 8$ and on $\mathrm{d} 150$. Conversely, group A cheeses were characterized by the highest counts of gram-negative bacteria on CFC medium (7.53 $\log _{10} \mathrm{cfu} / \mathrm{g}$ at $\left.\mathrm{d} 1\right)$ and halotolerant flora on $\mathrm{HO}$ medium $\left(7.02 \log _{10} \mathrm{cfu} / \mathrm{g}\right.$ at d 8). However, after $90 \mathrm{~d}$ of ripening, the microbial community was characterized by the highest counts on FH medium (7.95 $\log _{10} \mathrm{cfu} / \mathrm{g}$ at d 90 ).

The 3 cheeses manufactured with raw milk $\mathrm{B}$ microfiltrates were characterized by high counts on $\mathrm{FH}$ in milk to d 8 (3.95 $\log _{10} \mathrm{cfu} / \mathrm{g}$ in milk, $7.29 \log _{10} \mathrm{cfu} / \mathrm{g}$ at $\mathrm{d} 8$ ) and MSE medium (8.3 $\log _{10} \mathrm{cfu} / \mathrm{g}$ at d 8 ). Moreover, they showed the highest counts on BP medium at $\mathrm{d} 8\left(6.96 \log _{10} \mathrm{cfu} / \mathrm{g}\right)$ and on $\mathrm{HO}$ medium at $\mathrm{d} 150$ $\left(6.15 \log _{10} \mathrm{cfu} / \mathrm{g}\right)$. These characteristics remained stable throughout the ripening process for flora on BP medium, but counts on $\mathrm{FH}$ medium fell to their lowest point at $\mathrm{d} 150\left(7.2 \log _{10} \mathrm{cfu} / \mathrm{g}\right)$.

The 3 cheeses manufactured with microfiltrates from raw milk $\mathrm{C}$ were characterized by their higher counts on OGA medium in milk until $8 \mathrm{~d}$ of ripening (3.22 to $\left.5.89 \log _{10} \mathrm{cfu} / \mathrm{g}\right)$ and MSE medium at d $1\left(8.34 \log _{10} \mathrm{cfu} /\right.$ $\mathrm{g})$, higher counts on PCA from d 30 to d 150, on M17 at $\mathrm{d} 90$ and 150, and on MRS medium at $\mathrm{d} 1$ and $\mathrm{d} 150$. On the other hand, counts on OGA medium were lower after 1 mo of ripening.

According to the study of Callon et al. (2004), the microbial community pattern obtained here by counting on different media can be associated with the presence of some specific microbial genera (Table 1). Among lactic acid bacteria, the $\mathrm{FH}$ medium was the most selective, counting essentially the mesophilic Lactobacillus ( $L b$. casei and $L b$. plantarum). The SB medium counted mainly Enterococcus spp. but some Lactobacillus and
Leuconostoc could be detected. The MSE medium was selective for dextran-positive Leuconostoc but also counted mesophilic Lactobacillus spp. The M17 medium was more representative of total lactic acid bacteria. Moreover, the identification and typing of lactic acid bacteria performed by Callon et al. (2004) revealed more of the microbial species and strain diversity in the 3 cheeses made with $\mathrm{A}, \mathrm{B}$, and $\mathrm{C}$ raw milk specimens.

\section{Volatile Compound Analyses}

Thirty-one volatile compounds were quantified by dynamic headspace sampling high-resolution gas chromatography mass-spectrometry (Table 5). They belonged to several chemical families including acids (acetic acid, 3-methyl butanoic acid), alcohols (2-butanol, 3-methylbutanol, 2-heptanol), ketones (2, 3-butanedione, acetoin, 2-heptanone), esters (ethyl acetate, ethyl propionate), and aldehydes (3-methylbutanal). These compounds are essentially produced by sugar and amino acid catabolism or alcohol and acid esterification. A limited number of compounds derived from fatty acid oxidation were found, and sulfur compounds were not detected by the methodology used in this study. There was no qualitative difference between cheeses in the volatile compounds identified but the quantities of a few varied between cheeses. Indeed, the effects of the microflora added (from A, B, or C raw milk) and ripening time on volatile compound concentration in cheeses are summarized in Table 5. Results showed that cheeses manufactured with $\mathrm{B}$ retentate flora were distinguishable from the other 2 by their higher acetoin, 2,3-butanedione, and 3-methylpentanone desorption. Moreover, 2-butanone and 2-butanol alcohol were present in significantly lower concentrations in B cheeses.

\section{Sensory Characteristics}

Fifty-three descriptors for aroma, flavor, taste, and texture were used by the trained panel to describe the sensory characteristics of the experimental cheeses. Not all sensory attributes characterized Salers cheese specifically. Indeed, certain descriptors such as onion, yogurt, hay, grass, burning, smoked, astringent, and pungent were perceived by only 1 or 2 judges, and were thus eliminated from further analyses. Other descriptors (44) describing cheeses at d 90 and 150 were included in 2 ANOVA (results not shown). These 2 analyses elicited 16 sensory descriptors discriminating the cheeses with a significance of $P<0.1$, and 8 sensory descriptors discriminating the cheeses with a significance of $P<0.05$. The latter 8 descriptors (fermented cream aroma on d 90; caramel aroma on d 150; nut, garlicky, and chemical flavors on d 90; fresh cream, 
Table 4. Microbial counts $\left(\log _{10} \mathrm{cfu} / \mathrm{g}\right)$ on different media during manufacture and ripening of cheeses A, B, and C (mean values from 3 replicates). ${ }^{1}$

\begin{tabular}{|c|c|c|c|c|c|c|c|c|}
\hline \multirow[b]{3}{*}{ Counting media } & \multirow{3}{*}{$\begin{array}{l}\text { Time } \\
\text { of } \\
\text { ripening }\end{array}$} & \multicolumn{6}{|c|}{ Cheese $^{2}$} & \multirow[b]{3}{*}{ Significance } \\
\hline & & \multicolumn{2}{|c|}{$\mathrm{A}$} & \multicolumn{2}{|c|}{$\mathrm{B}$} & \multicolumn{2}{|c|}{$\mathrm{C}$} & \\
\hline & & Mean & $\mathrm{SD}$ & Mean & $\mathrm{SD}$ & Mean & $\mathrm{SD}$ & \\
\hline \multirow[t]{6}{*}{ Plate count agar, $30^{\circ} \mathrm{C}$} & Milk & 4.62 & 0.11 & 4.9 & 0.44 & 4.83 & 0.46 & NS \\
\hline & $1 \mathrm{~d}$ & 9.21 & 0.09 & 9.32 & 0.08 & 9.36 & 0.06 & NS \\
\hline & $8 \mathrm{~d}$ & 9.35 & 0.63 & 9.44 & 0.14 & 9.37 & 0.15 & NS \\
\hline & $30 \mathrm{~d}$ & $8.96^{b}$ & 0.08 & $9.28^{\mathrm{a}}$ & 0.09 & $9.31^{\mathrm{a}}$ & 0.08 & $* * *$ \\
\hline & $90 \mathrm{~d}$ & $\mathbf{8 . 6}^{\mathrm{b}}$ & 0.06 & $9.13^{\mathrm{a}}$ & 0.08 & $9.18^{\mathrm{a}}$ & 0.09 & $* * *$ \\
\hline & $150 \mathrm{~d}$ & $8.34^{b}$ & 0.25 & $8.78^{a}$ & 0.18 & $8.96^{\mathrm{a}}$ & 0.14 & $* *$ \\
\hline \multirow[t]{6}{*}{ De Man, Rogosa, Sharpe, $30^{\circ} \mathrm{C}$} & Milk & 4.48 & 0.21 & 4.43 & 0.13 & 4.49 & 0.66 & NS \\
\hline & $1 \mathrm{~d}$ & $9.03^{b}$ & 0.07 & $9.34^{\mathrm{a}}$ & 0.08 & $9.42^{\mathrm{a}}$ & 0.06 & $* * *$ \\
\hline & $8 \mathrm{~d}$ & 9.27 & 0.67 & 9.28 & 0.07 & 9.41 & 0.17 & NS \\
\hline & $30 \mathrm{~d}$ & $8.96^{b}$ & 0.04 & $9.2^{\mathrm{a}}$ & 0.06 & $9.18^{a}$ & 0.09 & $* * *$ \\
\hline & $90 \mathrm{~d}$ & $8.08^{b}$ & 0.57 & $8.87^{\mathrm{a}}$ & 0.08 & $8.85^{\mathrm{a}}$ & 0.29 & $*$ \\
\hline & $150 \mathrm{~d}$ & $8.16^{b}$ & 0.15 & $8.37^{b}$ & 0.15 & $8.67^{a}$ & 0.13 & $* *$ \\
\hline \multirow{6}{*}{$\begin{array}{l}\text { Facultative heterofermentative } \\
\text { medium, } 37^{\circ} \mathrm{C}\end{array}$} & Milk & $2.84^{b}$ & 0.24 & $3.95^{a}$ & 0.35 & $3.23^{b}$ & 0.45 & $* *$ \\
\hline & $1 \mathrm{~d}$ & $6.01^{b}$ & 0.18 & $6.87^{\mathrm{a}}$ & 0.11 & $6.32^{b}$ & 0.35 & $* *$ \\
\hline & $8 d$ & $6.7^{b}$ & 0.14 & $7.29^{a}$ & 0.07 & $7.07^{a}$ & 0.21 & $* * *$ \\
\hline & $30 \mathrm{~d}$ & $7.39^{a}$ & 0.24 & $7.31^{\mathrm{a}}$ & 0.05 & $7.1^{\mathrm{b}}$ & 0.07 & $*$ \\
\hline & $90 \mathrm{~d}$ & $7.95^{a}$ & 0.4 & $7.29^{b}$ & 0.1 & $7.05^{b}$ & 0.02 & $* *$ \\
\hline & $150 \mathrm{~d}$ & 7.33 & 0.11 & 7.22 & 0.07 & 7.08 & 0.13 & $*$ \\
\hline \multirow[t]{6}{*}{ M17 medium, $42^{\circ} \mathrm{C}$} & Milk & 4.51 & 0.16 & 4.52 & 0.46 & 4.54 & 0.61 & NS \\
\hline & $1 \mathrm{~d}$ & 9.1 & 0.05 & 9.23 & 0.23 & 9.36 & 0.12 & NS \\
\hline & $8 \mathrm{~d}$ & 8.91 & 1.15 & 8.96 & 0.11 & 9.19 & 0.16 & NS \\
\hline & $30 \mathrm{~d}$ & $\mathbf{8 . 3 9}^{b}$ & 0.36 & $8.84^{\mathrm{ab}}$ & 0.25 & $9.05^{a}$ & 0.09 & $* *$ \\
\hline & $90 \mathrm{~d}$ & $7.91^{b}$ & 0.21 & $8.44^{\mathrm{a}}$ & 0.23 & $8.77^{a}$ & 0.13 & $* * *$ \\
\hline & $150 \mathrm{~d}$ & 7.23 & 0.0 & 7.74 & 0.65 & 8.13 & 0.14 & $*$ \\
\hline \multirow[t]{6}{*}{ Slanetz Bartley medium, $42^{\circ} \mathrm{C}$} & Milk & 2.43 & 0.45 & 2.90 & 0.31 & 2.41 & 0.41 & NS \\
\hline & $1 \mathrm{~d}$ & 5.58 & 0.35 & 5.77 & 0.25 & 5.52 & 0.41 & NS \\
\hline & $8 \mathrm{~d}$ & 5.98 & 0.81 & 5.46 & 0.16 & 5.24 & 0.35 & NS \\
\hline & $30 \mathrm{~d}$ & 5.79 & 0.22 & 5.78 & 0.2 & 5.60 & 0.59 & NS \\
\hline & $90 \mathrm{~d}$ & 5.42 & 0.11 & 5.73 & 0.23 & 5.18 & 0.37 & $*$ \\
\hline & $150 \mathrm{~d}$ & 5.20 & 0.42 & 5.4 & 0.28 & 5.17 & 0.34 & NS \\
\hline \multirow{6}{*}{$\begin{array}{l}\text { Mayeux, Sandine, and Elliker } \\
\text { medium, } 30^{\circ} \mathrm{C}\end{array}$} & Milk & 2.8 & 0.05 & 3.45 & 0.2 & 3.38 & 0.75 & NS \\
\hline & $1 \mathrm{~d}$ & $7.02^{b}$ & 0.39 & $8.29^{a}$ & 0.28 & $8.34^{\mathrm{a}}$ & 0.04 & $* * *$ \\
\hline & $8 \mathrm{~d}$ & 7.4 & 0.51 & 7.71 & 0.5 & 8.16 & 0.07 & NS \\
\hline & $30 \mathrm{~d}$ & 7.7 & 0.37 & 7.16 & 1.1 & 7.19 & 0.54 & NS \\
\hline & $90 \mathrm{~d}$ & 6.98 & 0.32 & 7.08 & 0.38 & 6.94 & 0.24 & NS \\
\hline & $150 \mathrm{~d}$ & $6.03^{\mathrm{b}}$ & 0.85 & $7.48^{\mathrm{a}}$ & 0.3 & $7.06^{\mathrm{a}}$ & 0.49 & $*$ \\
\hline Hoyle medium, $37^{\circ} \mathrm{C}$ & Milk & 3.28 & 0.35 & 3.47 & 0.19 & 3.37 & 0.31 & NS \\
\hline & $1 \mathrm{~d}$ & 6.37 & 1.04 & 7 & 0.9 & 6.9 & 0.4 & NS \\
\hline & $8 \mathrm{~d}$ & $7.02^{a}$ & 0.6 & $6.89^{a}$ & 0.36 & $5.97^{b}$ & 0.23 & $* * *$ \\
\hline & $30 \mathrm{~d}$ & $6.08^{\mathrm{b}}$ & 0.31 & $6.83^{\mathrm{a}}$ & 0.32 & $5.76^{\mathrm{b}}$ & 0.75 & $*$ \\
\hline & $90 \mathrm{~d}$ & 4.93 & 0.53 & 5.43 & 0.48 & 5.07 & 0.42 & NS \\
\hline & $150 \mathrm{~d}$ & $5.08^{b}$ & 0.26 & $6.15^{a}$ & 0.59 & $5.38^{\mathrm{ab}}$ & 0.25 & $* *$ \\
\hline Baird Parker medium, $37^{\circ} \mathrm{C}$ & Milk & 2.68 & 0.21 & 3.01 & 0.05 & 2.79 & 0.32 & NS \\
\hline & $1 \mathrm{~d}$ & $6.45^{\mathrm{b}}$ & 0.36 & $6.96^{\mathrm{a}}$ & 0.03 & $6.65^{\mathrm{b}}$ & 0.15 & $*$ \\
\hline & $8 \mathrm{~d}$ & 6.17 & 0.49 & 6.65 & 0.31 & 6.12 & 0.44 & NS \\
\hline & $30 \mathrm{~d}$ & $6.08^{b}$ & 0.4 & $6.69^{\mathrm{a}}$ & 0.03 & $6.18^{b}$ & 0.06 & $* *$ \\
\hline & $90 \mathrm{~d}$ & 4.78 & 0.05 & 5.41 & 1.07 & 5.15 & 0.5 & NS \\
\hline & $150 \mathrm{~d}$ & $4.93^{\mathrm{b}}$ & 0.38 & $5.38^{\mathrm{a}}$ & 0.1 & $4.83^{\mathrm{b}}$ & 0.17 & $*$ \\
\hline Cetrimide-fucidin-cephalosporin & Milk & 3.18 & 0.21 & 3.31 & 0.15 & 2.79 & 0.03 & $*$ \\
\hline medium, $25^{\circ} \mathrm{C}$ & $1 \mathrm{~d}$ & $\mathbf{7 . 5 3} 3^{\mathrm{a}}$ & 0.16 & $6.7^{b}$ & 0.39 & $6.65^{b}$ & 0.25 & $* *$ \\
\hline & $8 \mathrm{~d}$ & 6.7 & 0.95 & 5.67 & 1.39 & 6.12 & 0.06 & NS \\
\hline & $30 \mathrm{~d}$ & $4.95^{b}$ & 0.55 & $4.76^{b}$ & 0.31 & $6.18^{\mathrm{a}}$ & 0.46 & $* * *$ \\
\hline & $90 \mathrm{~d}$ & 4.22 & 0.38 & 3.94 & 0.25 & 3.36 & 0.49 & $*$ \\
\hline & $150 \mathrm{~d}$ & 3.77 & 0.54 & 3.79 & 0.37 & 2.64 & 1.21 & NS \\
\hline Oxytetracycline glucose agar, $25^{\circ} \mathrm{C}$ & Milk & $2.13^{b}$ & 0.16 & $3.06^{\mathrm{a}}$ & 0.06 & $3.22^{\mathrm{a}}$ & 0.31 & $* * *$ \\
\hline & $1 \mathrm{~d}$ & 4.96 & 0.15 & 5.53 & 0.41 & 5.5 & 0.38 & NS \\
\hline & $8 \mathrm{~d}$ & $5.38^{b}$ & 0.04 & $5.66^{\mathrm{ab}}$ & 0.21 & $5.89^{\mathrm{a}}$ & 0.19 & $* *$ \\
\hline & $30 \mathrm{~d}$ & 5.53 & 0.3 & 5.47 & 0.7 & 5.77 & 0.2 & NS \\
\hline & $90 \mathrm{~d}$ & 4.84 & 1.3 & 6.34 & 0.52 & 5.62 & 0.99 & NS \\
\hline & $150 \mathrm{~d}$ & 3.76 & 0.75 & 4.35 & 0.79 & 3.57 & 0.42 & NS \\
\hline
\end{tabular}

${ }^{\mathrm{a}, \mathrm{b}}$ Means within row with different letters are significantly different $(P<0.1)$.

${ }^{1}$ Bold font indicates the most significant microbiological variables $(P<0.05)$.

${ }^{2}$ All cheeses were made with pasteurized milk A plus retentate (after microfiltration) from raw milks A, B, and C. Cheese A was prepared with milk A plus retentate A; Cheese B was prepared with milk A plus retentate B; Cheese $\mathrm{C}$ was prepared with milk A plus retentate C.

$* * * P<0.01 ; * * P<0.05 ; * P<0.1$; NS: $P>0.1$. 
Table 5. Volatile fraction contents (arbitrary units) desorbed by cheeses A, B, and C at d 150.

\begin{tabular}{|c|c|c|c|c|}
\hline & \multicolumn{3}{|c|}{ Cheese $^{1}$} & \multirow{2}{*}{$\begin{array}{l}\text { Statistical } \\
\text { significance }\end{array}$} \\
\hline & $\mathrm{A}$ & $\mathrm{B}$ & $\mathrm{C}$ & \\
\hline 2,3-Butanedione & 5.01 & 23.85 & 2.98 & $* *$ \\
\hline 2-Butanone & $456.5^{\mathrm{a}}$ & $95.94^{\mathrm{b}}$ & $369.85^{\mathrm{a}}$ & * \\
\hline 2-Butanol & $72.7^{\mathrm{a}}$ & $6.06^{\mathrm{b}}$ & $50.25^{\mathrm{a}}$ & * \\
\hline Acetic acid, ethyl ester & 2.80 & 19.99 & 35.40 & NS \\
\hline Acetic acid & 38.56 & 18.49 & 29.22 & NS \\
\hline 1-Butanol & 0.00 & 0.14 & 0.11 & NS \\
\hline 3-Methylbutanal & 2.18 & 5.98 & 3.75 & NS \\
\hline Propanoic acid & 0.07 & 0.13 & 0.00 & NS \\
\hline 2-Pentanone & 19.45 & 59.93 & 2.56 & NS \\
\hline 2-Pentanol & 0.96 & 1.46 & 0.07 & NS \\
\hline Acetoin & $23.2^{\mathrm{b}}$ & $145.33^{\mathrm{a}}$ & $30.48^{\mathrm{b}}$ & $* *$ \\
\hline Propanoic acid, ethyl ester & 0.02 & 0.10 & 0.06 & NS \\
\hline N-Propyl acetate & 0.08 & 0.24 & 0.12 & NS \\
\hline 3-Methylbutanol & 85.15 & 44.57 & 155.35 & NS \\
\hline 2-Methylbutanol & 9.02 & 6.88 & 10.47 & NS \\
\hline Disulphide, dimethyl & 0.03 & 0.06 & 0.02 & NS \\
\hline 3-Methylpentanone & $0.03^{b}$ & $0.72^{\mathrm{a}}$ & $0.001^{\mathrm{b}}$ & $* *$ \\
\hline Acetic acid, 1-methylpropyl ester & 0.08 & 0.03 & 0.04 & NS \\
\hline Butanoic acid & 2.26 & 11.37 & 1.33 & NS \\
\hline 2-Methylpentanal & 0.04 & 0.10 & 0.01 & NS \\
\hline Butanoic acid, ethyl ester & 1.36 & 4.22 & 4.10 & NS \\
\hline Butanoic acid, 3-methyl & 0.05 & 0.48 & 0.20 & NS \\
\hline Pentanoic acid & 0.01 & 0.04 & 0.01 & NS \\
\hline Butanol 3-methyl acetate & 1.87 & 1.70 & 2.14 & NS \\
\hline 2-Heptanone & 2.38 & 4.01 & 0.53 & NS \\
\hline 2-Heptanol & 0.32 & 0.13 & 0.06 & NS \\
\hline Butanoic acid, butyl ester & 0.30 & 0.09 & 0.05 & NS \\
\hline Hexanoic acid & 1.22 & 1.75 & 0.70 & NS \\
\hline Hexanoic acid, ethyl ester & 0.39 & 1.15 & 0.99 & NS \\
\hline Pyrazine, trimethyl & 0.01 & 0.06 & 0.00 & NS \\
\hline 2-Nonanone & 0.08 & 0.09 & 0.01 & NS \\
\hline Hexanoic acid, 2-methyl propyl ester & 0.00 & 0.00 & 0.00 & NS \\
\hline Octanoic acid, ethyl ester & 0.00 & 0.03 & 0.02 & NS \\
\hline
\end{tabular}

\footnotetext{
${ }^{\mathrm{a}, \mathrm{b}}$ Means within row with different letters are significantly different $(P<0.1$ or $P<0.05)$.

${ }^{1}$ All cheeses were made with pasteurized milk A plus retentate (after microfiltration) from raw milks A, B, and C. Cheese A was prepared with milk A plus retentate A; Cheese B was prepared with milk A plus retentate $\mathrm{B}$; Cheese $\mathrm{C}$ was prepared with milk $\mathrm{A}$ plus retentate $\mathrm{C}$ ( 3 replicates of each cheese).$$
* * P<0.05 ; * P<0.1 ; \text { NS: } P>0.1 \text {. }
$$

caramel, and cowshed flavors on d 150) were included in a principal component analysis as shown in Figure 2. The first 2 components accounted for $86.3 \%$ of the overall variation. Cheese discrimination was mainly based on PC 1 ( $68.4 \%$ of the inertia). The plotting of individuals on principal axes 1 and 2 (Figure 2B) produced an overall cluster for cheeses manufactured with the flora of milk from the same origin. Results of principal component analysis showed that cheeses manufactured with B milk flora formed a distinct group, characterized by nutty flavor on $\mathrm{d} 90$ and by the development of fresh cream and caramel flavors and caramel aroma on $\mathrm{d} 150$. The cheeses manufactured with $\mathrm{C}$ milk flora were localized on the right size of the principal component analysis. On d 90, they were characterized by a fermented cream aroma and garlicky, chemical flavors. They exhibited marked cowshed flavor on d 150. The cheeses manufactured with A milk flora had low aroma and flavor scores for the sensory attributes taken into account in the principal component analysis. Nevertheless, ANOVA results (data not shown) distinguished A cheeses by their highest fresh cream flavor score on $d$ $90(P<0.1)$, and their more intensive spicy aroma and cowshed flavor $(P<0.1)$ than in $\mathrm{B}$ and $\mathrm{C}$ cheeses on $\mathrm{d}$ 150 of ripening.

\section{Correlations Among Microbial and Sensory Characteristics}

The most significant microbiological variables $(P<$ 0.05; highlighted in bold in Table 4) were included in a principal component analysis (results not shown). In a second step, canonical correlation analysis was applied to get a better insight into the relationships between sensory profiles and microbiological characteristics.

Canonical correlation analysis of the links between microbiological and sensory data (Figure 3 ) revealed no 

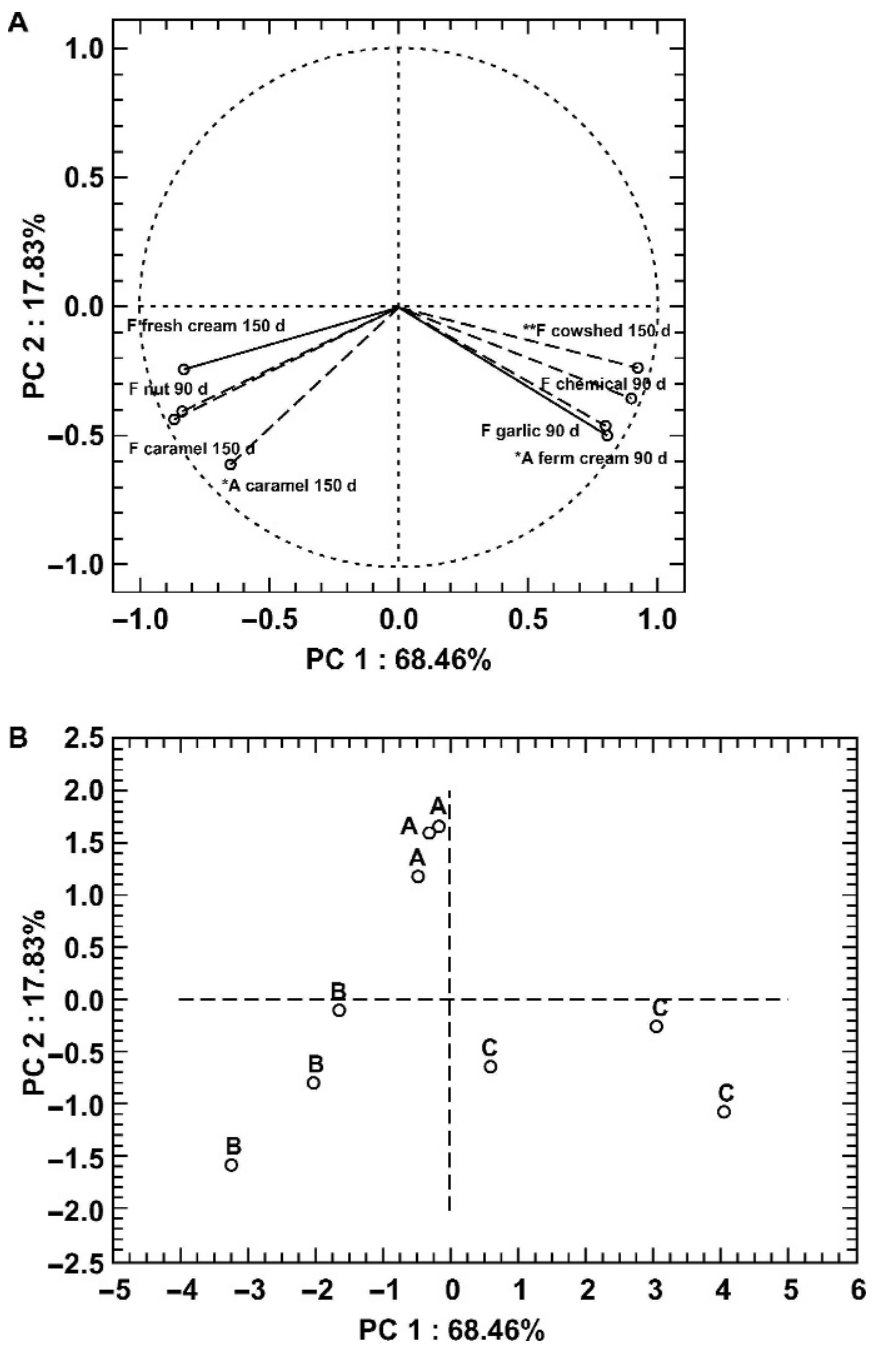

Figure 2. Principal components $(\mathrm{PC})$ analysis of the discriminate sensory analysis $(P<0.05)$ on d 90 and d 150. A) Attribute correlation circle $(\mathrm{A}=$ aroma, $\mathrm{F}=$ flavor); $\mathrm{B})$ Plot of cheeses $\mathrm{A}, \mathrm{B}$, and $\mathrm{C}$ (3 replicates each).

linear correlation. However, it is worth noting that the 3 cheeses, manufactured with the milk of the producer during a period of $1 \mathrm{mo}$, were spatially grouped by taking into account the microbial sensorial variables selected after the previous statistical analysis (highlighted in bold in Table 4). These results reveal some stability in the microbial communities of these cheeses from one batch to another through 1 mo of production. Likewise, cheeses from different cheese makings but made with the same milk microflora were distinguished by the same sensory attributes through this period. A link between the microbial community composition and the sensory characteristics of cheeses could then be established.

The sensory characteristics of all A cheeses (i.e., fresh cream and cowshed flavors on d 150) were associated

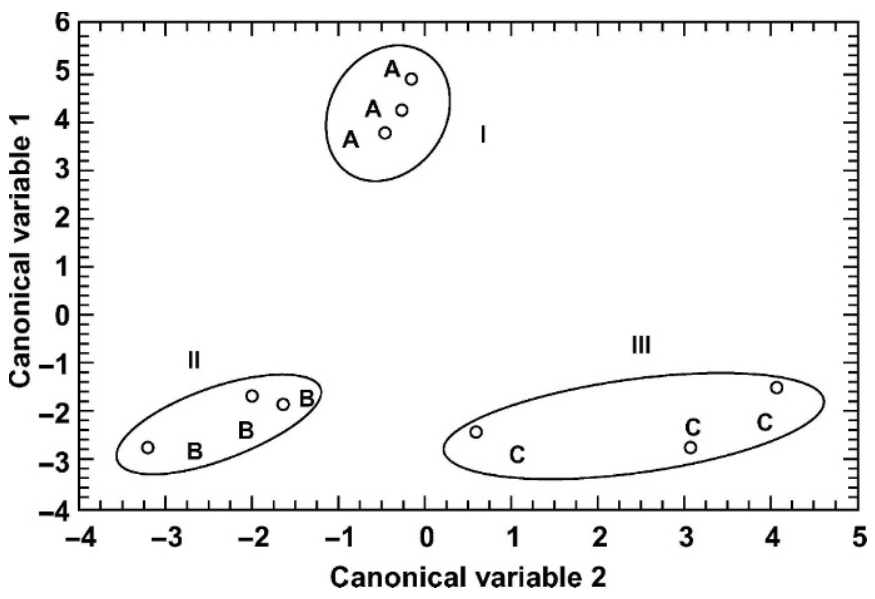

Figure 3. Canonical correlation analysis of microbiological data (significantly influenced by flora) and sensory data (significantly influenced by flora). I = Group A cheeses characterized by higher counts on Hoyle medium at d 8, and cetrimide-fucidin-cephalosporin medium at $\mathrm{d} 1$, higher counts on facultative heterofermentative (FH) medium at d 90, and low aromas and flavors except fresh cream and cowshed flavors at d 150; II = Group B cheeses characterized by higher counts on de Man, Rogosa, and Sharpe (MRS) medium on d 30, and on FH medium from d 0 (milk) to $\mathrm{d} 8$, higher counts on Baird Parker medium on d 30 , and Hoyle medium at d 150, higher nut flavor on d 90 and higher caramel aroma, fresh cream and caramel flavors at d 150; III = group C cheeses characterized by higher counts on oxytetracycline glucose agar in milk and on d 8, higher counts on MRS at d 150, higher counts on plate count agar from d 30 to d 150 and on M17 medium on d 30 and d 90, higher fermented cream aroma, chemical and garlic flavors on d 90, and higher cowshed flavor on d 150 .

with lower count on mesophilic lactobacilli on $\mathrm{FH}$ media and yeast count at $d 8$. However, mesophilic Lactobacillus became higher than in other cheeses at the end of ripening. High levels of gram-negative bacteria (counts on CFC media) at d 1 , flora count on HO media at d 8, and mesophilic lactobacilli at d 90 also characterized the microbial community of these A cheeses.

The sensory characteristics of B cheeses, characterized by fresh cream, hazelnut, and caramel, were associated with a high count of lactic flora on MSE at d 1, on FH at $d 1$ and $d 8$, on MRS media at d 1, and flora on $\mathrm{HO}$ and BP media at d 30 . High concentrations of 2,3 butanedione and acetoin (3-OH butanone) also characterized these cheeses. Diacetyl may be involved in fresh cream aroma in these cheeses, as they are known for their buttery notes (Antinone et al., 1994). Moreover, diacetyl production in cheeses has been often associated with Leuconostoc mesenteroides (Hemme and FoucaudScheunemann, 2004) and Lactobacillus (Menendez et al., 2000).

The sensory characteristics of $\mathrm{C}$ cheeses, defined by fermented cream, chemical, garlic, and cowshed attributes, were associated with a high level of yeasts on OGA medium at $d 8$ and a higher level of bacteria on MRS at $\mathrm{d} 1$ and M17 medium after d 30 and $d 90$. 
The lack of linear correlation is not surprising as the composition of microbial community of these PDO Salers cheeses is complex as revealed in the studies of Callon et al. (2004) and Duthoit et al. (2003). Consequently, flavor development in these cheeses results from numerous complex microbial interactions; the balance and interaction among aromatic compounds are fine.

Some correlations have been reported in the literature between the inoculation of a microbial species and the sensory characteristics of cheese. Most studies have dealt with the inoculation of a few bacterial species in pasteurized milks under conditions quite different than in our study. For example, it was reported that adding Lactobacillus strains to pasteurized milk was negatively correlated with acid and bitter tastes and induced butter and spicy flavors in semihard cheeses made from cow milk (Gomez et al., 1996) and in Arzua-Ulloa cheeses (Menendez et al., 2000). Adding Enterococcus faecalis to pasteurized milk to make Cebreiro cheese led to more acid, rancid, and spicy sensory characteristics (Centeno et al., 1999). Correlations between yeasts (particularly Debaryomyces hansenii and Yarrowia lipolytica) and bitter, strong organoleptic characteristics in pasteurized-milk Cheddar cheeses have been noted (Ferreira and Viljoen, 2003). Yeasts (Kluyveromyces lactis in particular) induced strong and fruity organoleptic characteristics in cheese curd (Martin et al., 1999).

In our study, the correlation between microbial flora and sensory properties was most difficult to establish because the microbial communities inoculated in our cheeses were complex. These microbial communities were a balance between different microbial populations without dominance of one species.

\section{CONCLUSIONS}

This study is in agreement with that of Demarigny et al. (1997), which showed that with the same technology and raw material, the sensory properties of cheese could be varied by inoculating different microbial communities. It argues for maintaining microbial diversity in milk to preserve the richness and diversity of raw milk cheeses, which are largely recognized for their sensory properties (Cimons, 2001). Nevertheless, no direct correlation was found between microbiological and sensory data. It seems that a given milk microbial community remains relatively stable in its composition over $1 \mathrm{mo}$. In the Salers-type cheeses under study, the differences in microbial communities were revealed by counting flora on different media. This diversity was also underlined by identifying lactic acid bacteria (Callon et al., 2004) and bacterial dynamics in these Salers cheeses (Duthoit et al., 2003). Our results highlighted that flavor production in cheese results from a complex ecosystem (Delahunty and Piggott, 1995). Further studies will be undertaken to understand how these microbial populations interact in cheese matrices to confer the typical characteristics of those cheeses.

\section{ACKNOWLEDGMENTS}

We acknowledge the support of the "Pôle Fromager AOC Massif Central". We are very grateful to the "Comité International des Fromages" and its sensory panelist for performing sensory analyses. Thanks also to A. Laguet for the physicochemical analysis of the cheeses, and to the Salers farmers for their participation in this project. We thank R. Lavigne and R. Didienne for the cheesemaking and B. Desserre for microbial analyses, and Philip Rousseau-Cunningham for English proofreading.

\section{REFERENCES}

AFNOR. 1985. Lait, crème et lait concentré non sucré. Détermination de la matière sèche. Standard NF V 04-367. Association Française de Normalisation (AFNOR), Paris La Défense, France.

Antinone, M. J., H. T. Lawless, R. A. Ledford, and M. Johnston. 1994. Diacetyl as flavour component in full fat cottage cheese. J. Food Sci. 59:38-42.

AOAC. 1990. Official Methods of Analysis. 15th ed. Association of Official Analytical Chemists, Arlington VA.

Baird-Parker, A. C. 1962. An improved diagnostic and selective medium for isolating coagulase-positive staphylococci. J. Appl. Bacteriol. 25:12-19.

Bouton, Y., P. Guyot, A. Dasen, and R. Grappin. 1994. Activité protéolytique de souches de lactobacilles thermophiles isolées de levain et de Comté. II- Applications en sites industriels. Lait 74:33-46.

Buchin, S., V. Delague, G. Duboz, J. L. Berdagué, E. Beuvier, S. Pochet, and R. Grappin. 1998. Influence of pasteurization and fat composition of milk on the volatile compounds and flavor characteristics of a semi-hard cheese. J. Dairy Sci. 81:3097-3108.

Callon, C., F. Duthoit, L. Millet, and M. C. Montel. 2004. Diversity of lactic acid bacteria in AOC Salers cheese. J. Dairy Res. 71:231-244.

Centeno, J. A., S. Menendez, M. A. Hermida, and J. L. RodriguezOtero. 1999. Effects of addition of Enterococcus faecalis in Cebreiro cheese manufacture. Int. J. Food Microbiol. 48:97-111.

Cimons, M. 2001. Food safety concerns drive FDA review of fine cheeses. ASM News 67:1-6.

Dasen, A., C. Piton, R. Grappin, and P. Guerry. 1987. Evaluation de la technique DEFT associée à un comptage visuel ou à un comptage par analyseur d'images pour la numération de la flore totale du lait cru. Lait 67:77-95.

de Man, J., M. Rogosa, and M. E. Sharpe. 1960. A medium for the cultivation of Lactobacilli. J. Appl. Bacteriol. 23:130-135.

Delahunty, C. M., and J. R. Piggott. 1995. Current methods to evaluate contribution and interactions of components to flavour of solid foods using hard cheese as an example. Int. J. Food Sci. Technol. 30:555-570.

Demarigny, Y., E. Beuvier, S. Buchin, S. Pochet, and R. Grappin. 1997. Influence of raw milk microflora on the characteristics of Swiss-type cheeses: II. Biochemical and sensory characteristics. Lait 77:151-167.

Duthoit, F., J. J. Godon, and M. C. Montel. 2003. Bacterial community dynamics during production of Registered Designation of Origin Salers cheese as evaluated by 16S rRNA gene single strand con- 
formation polymorphism analysis. Appl. Environ. Microbiol. 69:3840-3848.

Ferreira, A. D., and B. C. Viljoen. 2003. Yeasts as adjunct starters in matured Cheddar cheese. Int. J. Food Microbiol. 86:131-140.

FIL-IDF. 1991. Lait et produits laitiers. Dénombrements des microorganismes, comptage des colonies à $30^{\circ} \mathrm{C}$. FIL 100B. Fédération Internationale de Laiterie, Brussels, Belgium.

Gomez, M. J., P. Gaya, M. Nunez, and M. Median. 1996. Effect of Lactobacillus plantarum as adjunct starter on the flavor and texture of a semi hard cheese made from pasteurised cow's milk. Lait 76:461-472.

Grappin, R., and E. Beuvier. 1997. Possible implications of milk pasteurization on the manufacture and sensory quality of ripened cheese. Int. Dairy J. 7:751-761.

Heiss, E. 1961. Versuche zur bestimmung des Käse fett gehaltes mit hilfe von schnellmethoden. Dtsch. Molk. Ztg. 82:67-70.

Hemme, D., and C. Foucaud-Scheunemann. 2004. Leuconostoc, Characteristics, use in dairy technology and prospects in functional foods. Int. Dairy J. 14:467-494.

IDF. 1982. Determination of the total solids content: Gravimetric (cheese and processed cheese), IDF Standard 4A. International Dairy Federation, Brussels, Belgium.

IDF. 1991. Determination of free fatty acids in milk and milk products. IDF Standard 265. International Dairy Federation, Brussels, Belgium.

IDF. 1993. Determination of nitrogen content. IDF Standard 20B. International Dairy Federation, Brussels, Belgium.

IDF. 1996. Whole milk: Determination of milk fat, protein and lactose content-guide for the operation of mid-infra-red instruments. IDF Standard 141B. International Dairy Federation, Brussels, Belgium.

ISO. 2000. Microbiologie des Aliments. Méthode horizontale pour la recherche et le dénombrement des Pseudomonas spp. ISO standard 13720, International Standards Organisation, Geneva, Switzerland.

Isolini, D., M. Grand, and H. Glättli. 1990. Selektivmedien zum Nachweis von obligat und fakultativ heterofermentativen Laktobazillen. Schweiz. Milchw. Forsch. 19:57-59.

Kondjoyan, N., and J. L. Berdagué. 1996. A compilation of relative retention indices for the analysis of volatile compounds. Edition du Laboratoire Flaveur. Station de recherche sur la viande, INRA de Theix, Saint Genes Champanelle, France.

Martin, B., J. B. Coulon, J. F. Chamba, and C. Bugaud. 1997. Effect of milk urea content on characteristics of matured Reblochon cheeses. Lait 77:505-514.

Martin, N., S. Savonitto, P. Molimard, C. Berger, M. Brousse, and H. E. Spinnler. 1999. Flavor generation in cheese curd by coculturing with selected yeast, mold, and bacteria. J. Dairy Sci. 82:10721080

Mayeux, J. V., W. E. Sandine, and P. R. Elliker. 1962. A selective medium for detecting Leuconostoc organisms in mixed-strain starter cultures. J. Dairy Sci. 45:655-656.

Menendez, S., J. A. Centeno, R. Godinez, and J. L. Rodriguez-Otero. 2000. Effects of Lactobacillus strains on the ripening and organoleptic characteristics of Arzua-Ulloa cheese. Int. J. Food Microbiol. 59:37-46.

Montel, M. C., J. L. Berdagué, C. Callon, E. Dufour, and S. Hulin. 2001. Rapport final de contrat ONILAIT. Rôle de microflore du lait cru sur les caractéristiques sensorielles des fromages affinés: application à l'AOC Salers.

Mossel, D. A. A., A. M. C. Kleynen-Semmeling, and H. M. Vincente. 1970. Oxytetracycline-glucose-yeast-extract agar for selective enumeration of moulds and yeasts in foods and clinical material. J. Appl. Bacteriol. 33:454-457.

Pons, B. J., F. Duchiron, F. Duperray, A. Guyonvarch, S. Melaouene, and J. More. 1993. Conservation de souches et milieux spécifiques. Page 414 in Les corynébactéries. Microbiologie industrielle, Les micro-organismes d'intérêt industriel. J. Y. Leveau and M. Bouix, ed. Lavoisier, Technique et Documentation, Paris, France.

Rehman, S. U., J. M. Banks, E. Y. Brechany, D. D. Muir, P. L. H. McSweeney, and P. F. Fox. 2000. Influence of ripening temperature on the volatiles profile and flavor of Cheddar cheese made from raw or pasteurised milk. Int. Dairy J. 10:55-65.

Slanetz, L. W., and C. H. Bartley. 1957. Numbers of enterococci in water, sewage, and faeces, determined by the membrane filter technique with an improved medium. J. Bacteriol. 74:591-596.

Terzaghi, B. E., and W. E. Sandine. 1975. Improved medium for lactic streptococci and their bacteriophages. Appl. Microbiol. 29:807813. 